\title{
Quality Teaching in Online Higher Education: The Perspectives of 250 Online Tutors on Technology and Pedagogy
}

\author{
https://doi.org/10.3991/ijet.v16i06.20173 \\ Dimitrios Vlachopoulos $(\bowtie)$ \\ Amsterdam University of Applied Sciences, Amsterdam, Netherlands \\ d.v.vlachopoulos@hva.nl \\ Agoritsa Makri \\ European University Cyprus, Nicosia, Cyprus
}

\begin{abstract}
Over the past few decades, education systems, especially in higher education, have been redefined. Such reforms inevitably require reconsideration of operational notions and definitions of quality, along with a number of related concepts. This reconsideration aligns with the core of higher education reforms: improving efficacy and compatibility with emerging social demands while adapting to competitiveness and accountability trends. As primary players in the teaching and learning process, online tutors have a protagonistic role and, therefore, must be equipped with a suitable set of competencies and attributes in addition to content knowledge. This quantitative research aims to analyze the perceptions of 250 online tutors working in European higher education institutions, distributed in 5 knowledge areas: Business, Education, Humanities, Sciences and Health. This descriptive and exploratory nonexperimental study reveals the technological and pedagogical skills and competencies that online tutors consider fundamental for effective online teaching and proposes professional development actions to ensure quality online teaching.
\end{abstract}

Keywords - Quality online teaching, online teaching, online higher education, online tutors, quantitative research

\section{Introduction}

Over the past few decades, higher education systems have acquired a dynamic vision, aiming to reflect and support the diverse interests of the student population, employers and society in general. These diverse interests have created challenges, requiring reconsideration of operational notions and definitions of quality, along with a number of related concepts [1]. This reconsideration aligns with the core and foundation of higher education reforms: improving efficiency and aligning with rising social needs and challenges while adapting to the current trends related to competitiveness and accountability [2]. Terms and concepts that had previously used only in the business sector are now emerging in discussions about higher education. Addi- 
tionally, quality, evaluation, efficiency, competitiveness and accountability are now the focus of sophisticated analyses by policymakers in higher education [3].

Various growth rates within our current global society lead to new products and services and to the continuous quality improvement of existing ones [4]. This growth requires continuous efforts to gain competitive advantage as far as the value and the quality of the services and products are concerned. This value is based on creating products or services that not only meet the relevant quality definitions but are also continuously evaluated. According to Tremblay and Kish [5], the growing interest in quality in higher education is related to the emergence and/or expansion of private institutions, as well as the diversification of existing education and training models, including distance and online education, which are increasing the demand for "better consumer protection" (p.260). Thus, online education has already been recognized as a key factor in the reconfiguration of quality assurance [6]

As protagonists of the teaching and learning process, online tutors play a key role in online education and, therefore, must develop an appropriate set of competencies and attributes in addition to subject matter knowledge [7]. The provision of online education programs also involves selecting educators with both technology and pedagogy skills, which are necessary for the facilitation and management of online instruction $[8,9]$. This study aims to critically reflect on the perceptions of academics about the skills and characteristics that successful online tutors should possess and to propose actions to improve the quality of online teaching.

\subsection{Online tutors: conceptual investigation and their role in online education}

You E-learning has been gaining ground among learning models because of its efficiency but also because of the proliferation of a multitude of studies which aim at enacting positive change in the education process [10]. In the complex situation created by the introduction of technological tools and applications in the educational process, we must reconsider the methods, strategies and instruments used in teaching [11, 12]. Online instructors (tutors) play a key role in this reconsideration process because they do not convey content in the same way that they would in the context of face-toface (conventional) teaching because students are in possession of content acquired in their own way and at their own pace [13]. Before explaining in more detail the role of online tutors, it is necessary to present the different names that they acquire in the current literature. In most reviewed articles, the term "online tutor" [14] is adopted. Other articles use the terms "(online) adjunct faculty member", especially in the Anglo-Saxon region [15], "online teacher/instructor" [16], "online facilitator" [17], "online consultant" [18], "collaborating faculty member" [19], and "online mentor" [20]. According to Llorente [10] and Fernández-Jiménez, Tójar-Hurtado and MenaRodríguez [11], online tutors perform the following functions: 
- Academic function: This function is directly related to the student's mastery of content, activities, diagnosis and formative evaluation of students, and the skills required in organizing these activities

- Technical function: This feature aims to assure students' mastery of the tools available in the virtual environment

- Guidance function: This function's main objective is the development of the ability to plan, structure and set operating rules, as well as to program over time and to execute the teaching tasks

- Social function: This function aims to avoid feelings of isolation and the loss or lack of motivation among students who study online

- Organizational function: This function refers to the task of guiding and advising students on organizational issues during the development of training activities

An understanding of the abovementioned features can help us to investigate their vital and multifaceted roles in supporting student learning and to understand the complexity of these roles because tutors perform these functions simultaneously.

\subsection{The profile and competencies required for online tutors: Institutional implications}

Although traditional teachers, who are engaged in conventional/onsite teaching, have acknowledged e-learning as a new teaching paradigm for university students [13], they continue to question the effectiveness of online learning [21]. Teachers' distrust of e-learning is represented by the preference of conventional universities to hire teaching staff who have pursued their studies in traditional/face-to-face institutions [22]. Online teachers who can be more involved and efficient in a virtual environment are essential for the growth and success of higher education institutions. However, only few academic leaders consider that their teaching staff believe in the legitimacy and value of the online instruction [23]. Given this context, it is important to encourage online teaching in terms of the academic success of online students, since the development of online education requires a committed, capable and sufficient number of teaching staff to meet the current demand. Below, the most important characteristics and competencies for online tutors, according to credible literature, are presented.

\section{Personal profile}

Although recent studies highlight that there are no gender differences in teachers' job satisfaction [24], we can report important differences in the satisfaction of the students on their teacher's gender role. Specifically, Gappa, Austin and Trice [25] concluded that students prefer their teachers to possess both feminine and masculine attributes, regardless of their gender (i.e., sensitive and assertive). It can be argued that the online class becomes a unique space, which allows the teaching staff to mask their individual attributes (i.e., gender), and to empower their interaction and collaboration with their students in a very organized way [26]. Since students demonstrate their preference towards teaching staff who show empathy and leadership, it is rec- 
ommended that teacher development initiatives place more emphasis on asynchronous interaction strategies that take advantage of teacher preference characteristics. For instance, teachers can be offered training on effective ways to convey emotions in the context of an asynchronous discussion, where expressiveness and other nonverbal indicators are not present.

According to the corresponding literature [26, 27], online teachers have an average age of approximately 40-42 years. However, a large standard deviation has been identified, and the age of online teachers ranges from 25 to 70 years. Thus, the ages of online teachers suggest considerable variability in their professional development. Moreover, the differences in age is an indication of the differential effectiveness of various types of teacher training.

Mandernach, Register and O'Donnell [26] indicate that most online professors $(60 \%)$ have master's degrees, and 35\% have doctoral degrees. The authors also emphasize that a substantial proportion of those who have obtained a master's degree are pursuing doctoral studies to become more competitive in the labor/university market. Thus, these teachers can be viewed as fully committed to the academic community and continue to build their academic profile. We can talk about "transitional faculty" providing useful insight to help institutions develop teacher training and professional development programs to be more receptive to the today's students' needs.

One of the most significant elements that emerges from the process of reflection and discussion on online teachers is the necessary qualities for teachers within a virtual learning environment to possess. According to Ornellas and Romero [28], these qualities refer to a number of skills:

- Pedagogical skills: Related to the teacher's skills with the different teachinglearning methodologies, the degree of mastery of the subject content, the experience in teaching-learning in a certain field of knowledge, etc.

- Cognitive skills: Related to the joint construction of knowledge. These skills include research skills; information processing, interpretation, organization and presentation; process management; and evaluation. The teacher must be able to organize a coherent learning experience within areas of knowledge for which a considerable amount of information is available but not always organized coherently.

- Technological and instrumental skills: Related to the knowledge and mastery of ICT from the user's perspective; mastery of written language to facilitate nonverbal communication processes with classmates; etc.

- Communication and social skills: Related to the ability to work in a team; the ability to exchange knowledge and ideas in a constructive way; effective communication with the whole educational community (other teachers, students, etc.); regular interaction or interaction habits; negotiation and conflict resolution; proactivity; etc.

- Personal skills: Related to the planning and organization of personal work, the ability to manage teaching time and the regulation of academic time of participants, shared commitment, flexibility, perseverance, initiative, discipline, empathy, motivation, etc. 


\section{Teaching / professional profile}

On average, online teachers have 7 years of university teaching experience with an average of 4 years in an online environment [29]. Again, we observe a large deviation, with teachers having no experience to more than 15 years of university teaching experience. While assessments of online teaching students show little difference in perception of instructional effectiveness based on experience [30], recognition of variability in teaching experience is a fundamental element of an efficient training or professional development program. If we compare the average age of teachers with the average age of their experience in teaching, it is evident that most teachers entered university education (and e-learning) after spending part of their professional life in another profession. Therefore, teacher development programs that aim to support online teachers require to go beyond training in e-learning strategies and include knowledge about pedagogical concepts, theories and strategies.

In addition, nearly half of teachers currently teaching online courses are simultaneously working in traditional/face-to-face education [26].

Finally, a large percentage of teachers are teaching simultaneously at more than one institution. While teaching at various institutions increases their teaching experience [31], it also raises concerns about copyrights and ownership of the course materials used. When teaching face-to-face, all the learning materials used are directly related to synchronous teaching presentations and interactions. In the virtual classroom, on the other hand, there is often a differentiation between static teaching material in a course and teacher facilitation [26]. Although the course facilitation is acknowledged as the property of the instructor, the learning materials are owed by the institution. Teacher training and development programs must emphasize intellectual property to ensure that it is considered in an ethical manner by all involved.

\section{Institutional implications: Synthesis}

After analyzing the profiles of online teachers and the skills needed to successfully perform in this role, institutions should:

- Provide specific training in asynchronous interaction and collaboration strategies, which encourage teachers' social, as well as emotional, presence in the virtual class

- Organize and plan teacher professional development programs with special focus on pedagogical concepts, theories and strategies

- Increase the technical knowledge of "transition teachers" by providing valuable information to ensure that training and development programs are responding to the needs of modern students

- Provide clear guidance on the expectations and policies related to intellectual property and the ownership of teaching materials in online teaching and learning

- Provide professional development initiatives in a variety of ways (expository, collaborative, synchronous, asynchronous, etc.), which encourage teacher engagement regardless of age, technical/technological skills, or previous experience in online instruction 
- Foster professional networks between online teachers from different bibliographic areas

- Propose a system for the recognition of online teacher credentials, following the example of the system that exists for face-to-face teaching

\section{$2 \quad$ Methodology}

This research is a descriptive and exploratory study using a quantitative approach. Its design is nonexperimental [32], since there is neither intentional manipulation nor random assignment, only observation of existing situations in their natural context, since the subjects studied already belonged to a certain group and level (online tutors). In addition, it is cross-sectional, since data are investigated in a single moment and a single time [33], with the objective of describing variables that make up the participants' perceptions of an ideal online tutor and analyzing their attitudes regarding the concept of quality. This positivist methodology [34] is based on a nomothetic perspective; that is, it approaches reality as it is classified in the world (ontology). The main reason for choosing a positivist approach is that the results can be considered reliable and representative and are generalizable to a larger population [35]. This research is part of the approved research program " e-learning Quality Assurance Design Standards in Higher Education" financed by Laureate Education in the context of the David Wilson Award for Excellence in Teaching and Learning (won by the first author).

\subsection{Participating population}

The study population consisted of online tutors from higher education institutions located in Cyprus, Greece, the United Kingdom and Spain. The online tutors were distributed across 5 areas of knowledge: Economics and Business Administration Studies, Education Studies, Humanities Studies, Science Studies and Health Studies. This number of participants led us to choose a quantitative methodology, which allowed relatively fast and easy access to a large population [36]. Written informed consent was obtained from all participants.

\subsection{Data collection}

The participants received a questionnaire that was divided into 5 main parts and contained 62 closed questions. The first part comprised the consent form; the second part included demographic questions about the participating population; the third part included questions about the participants' professional/work situation; the fourth part included 20 questions about the training necessary to successfully perform the work of an online tutor; and the fifth part comprised 32 questions about the characteristics and most important competencies of an online tutor.

Cronbach's alpha is used to evaluate the reliability or internal coherence of a set of scale elements [37]. The tables 1 and 2 present the $\alpha$ coefficients of the two main parts 
of the questionnaire sent to our participating population and allow us to discuss its reliability or acceptable internal coherence.

Table 1. Cronbach's alpha for questions about training needs

\begin{tabular}{|c|c|c|}
\hline \multicolumn{3}{|c|}{ Reliability Statistics } \\
\hline Cronbach's Alpha & Cronbach's Alpha Based on Standardized Items & N of Items \\
\hline .638 & .651 & 20 \\
\hline
\end{tabular}

Table 2. Cronbach's alpha for the questions about the profile and characteristics of tutors

\begin{tabular}{|c|c|c|}
\hline \multicolumn{3}{|c|}{ Reliability Statistics } \\
\hline Cronbach's Alpha & Cronbach's Alpha Based on Standardized Items & N of Items \\
\hline .630 & .634 & 32 \\
\hline
\end{tabular}

\section{Results and Discussion}

\subsection{Demographics}

\section{Gender}

$52 \%$ of the participants in our study were men, and $48 \%$ were women. This balanced distribution between men and women allows us to say that both genders are satisfactorily represented. In addition, the high level of participation (86.2\%) of the total population ensures that the results can be generalized to other institutions with similar characteristics.

Figure 1 shows the age distribution of the participating population, which indicates that $77.6 \%$ are between 30 and 49 years of age.

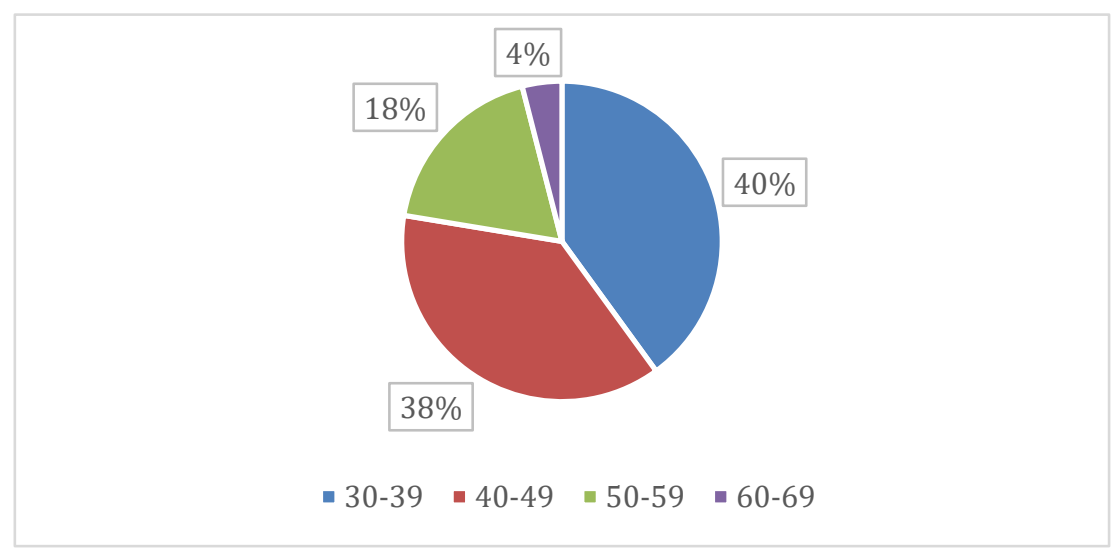

Fig. 1. Participants' age distribution (years)

These results are consistent with the corresponding literature [26, 27] on the average age of online teachers (40-42 years). It also confirms that there are people of all 
ages participating in e-learning, which means that we must consider the characteristics and needs of multiple age groups when designing training and development programs. Undoubtedly, the wide age range can be an indicator of the differential effectiveness of various types of teacher education.

\section{Teaching category}

Figure 2 shows the teaching category distribution among the participants involved with online studies at the participating universities.

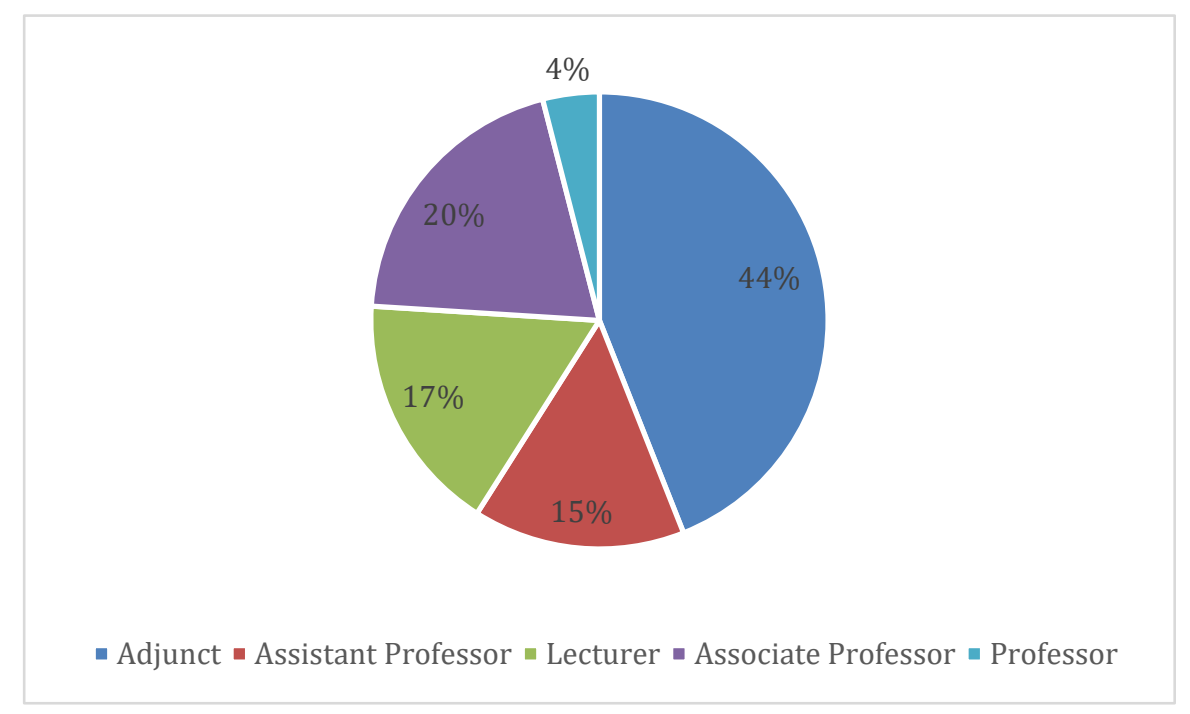

Fig. 2. Teaching categories of the participants

In this context, it should be explained that the participating universities follow the teaching categories/ranks used in the United States. According to this categorization, "adjunct" teachers are teaching staff hired only for online courses. These people are hired every semester according to the teaching needs of the university. The results confirm the statement of Mandernach, Register and O'Donnell [26] that almost half of the people teaching online courses also provide face-to-face education. In our case, $56 \%$ of the participants were also hired to teach face-to-face classes at the same university or at another university.

Figure 3 represents the distribution of the participants across the different areas of knowledge. In the participating universities 5 areas of knowledge have been identified: Economics and Business Administration Studies, Education Studies, Humanities Studies, Science Studies and Health Studies. 


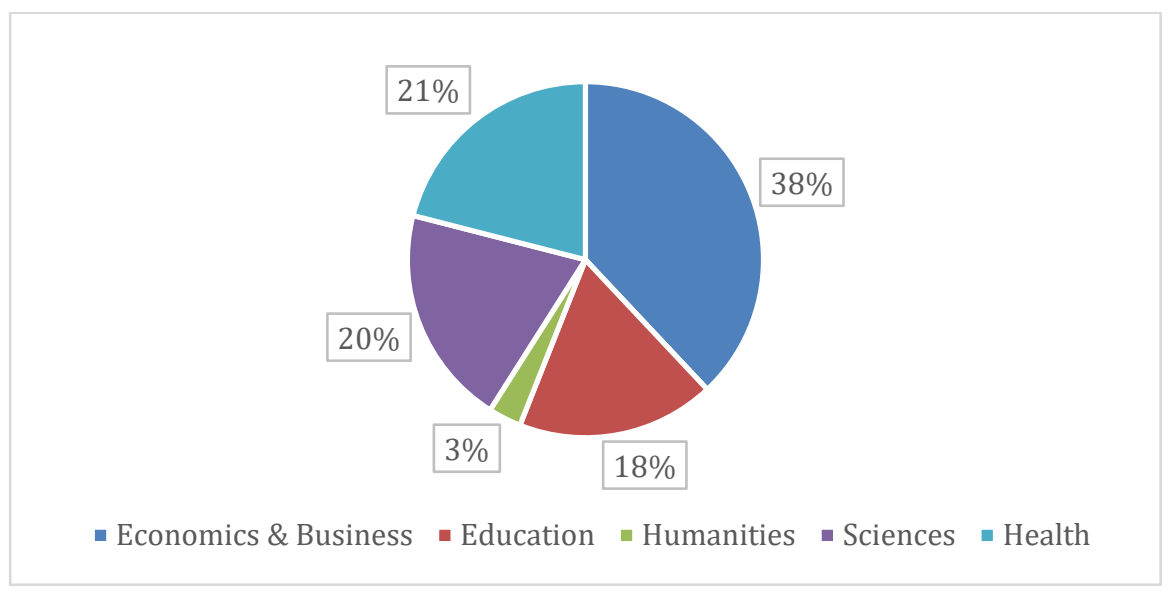

Fig. 3. Distribution of participants into areas of knowledge

Figure 3 also shows the popularity of online programs at participating universities. Specifically, the economics and business programs (MBA, MSc Marketing, Communication and Social Media, MSc Management) are the most popular and comprise the largest number of teachers (38\%), followed by the sciences (MSc Computer Science, MSc Artificial Intelligence \& MSc Information Systems), health (Master in Public Health, MSc in Psychology) and education (MA in Education) programs. Humanities programs are less popular (following the trend in face-to-face programs).

\section{Years of experience}

As shown in Figure 4, the participants have approximately 15 years of experience as university professors on average and approximately 5 years on average as university professors online. These results should be considered when preparing teacher training and development programs, and greater emphasis should be placed on the development of skills for online teaching, since the participating population has much less exposure to this new model of teaching and learning.

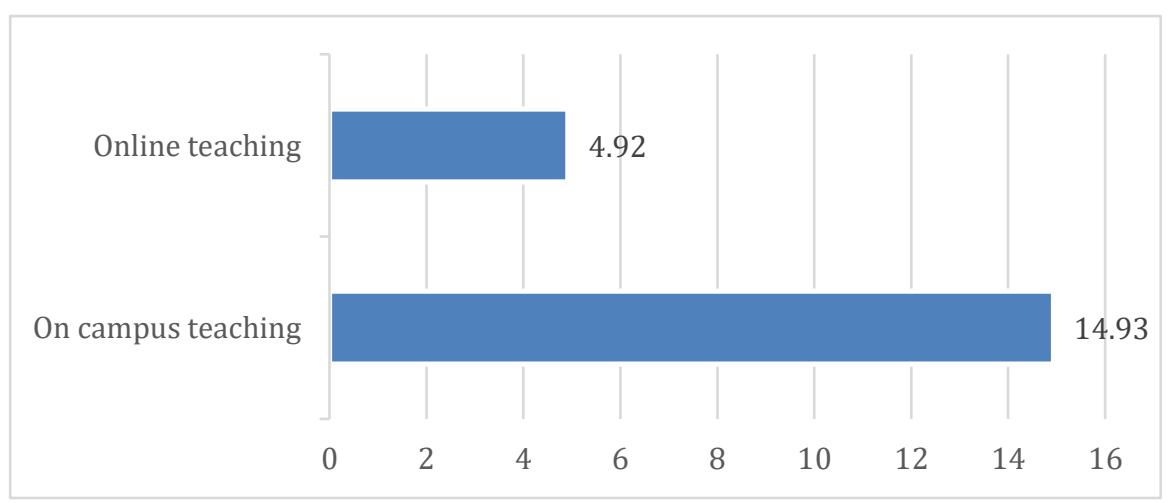

Fig. 4. Mean years of teaching experience (years) 


\subsection{Profile and competencies}

The 250 participating teachers assessed 32 characteristics/competencies that are a priority for online tutors according to the corresponding bibliography using a scale from 1 (lowest score) to 5 (highest score). The characteristics/competencies that obtained the highest score (mean) are presented in Figure 5.

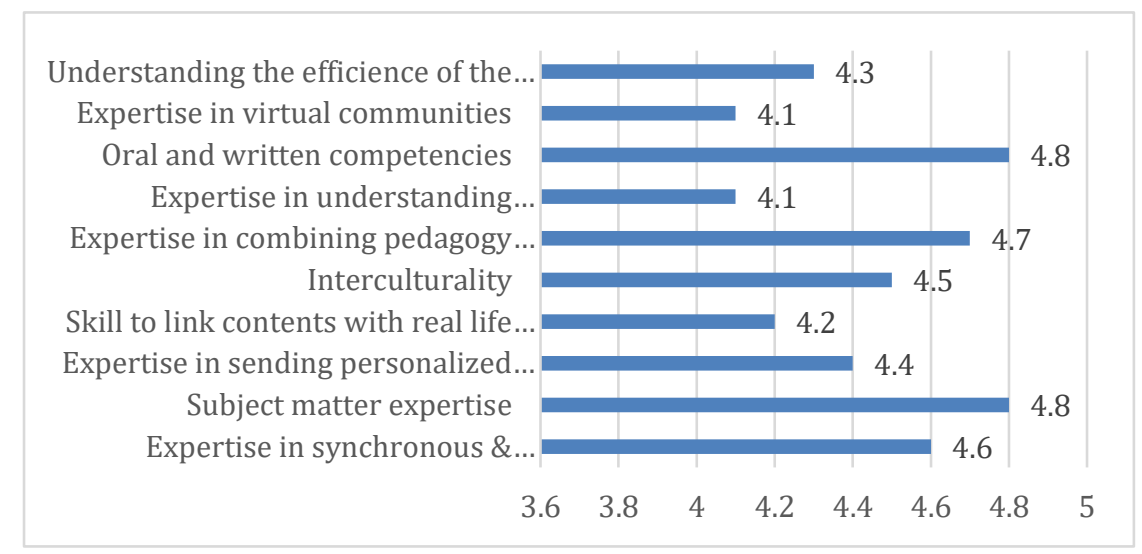

Fig. 5. Mean assessment of online tutor's competencies/characteristics

The participating population confirms the current literature regarding the most important characteristics and competencies that online tutors must demonstrate. First, the findings of Thorpe [17], who also highlighted the importance of experience in the field of knowledge, are confirmed. Participants rated this characteristic 4.8/5. Oral and written expression abilities obtained the same score (4.8/5), confirming Bens [38], who emphasizes the importance of communication in training processes, especially when training takes place through technological means. In line with Burke et al. [39], our participants highlighted the importance of online tutors being able to combine pedagogy and their theories on teaching and learning with the use of technology $(4,7 / 5)$. The most important determinants of the use of technology include the teachers' access to technology, their degree of concern regarding the adoption of technology and their particular pedagogical orientation. These determinants should be taken into account when designing training and development programs for teachers. Interculturality was another competence that was highly valued by the participants in this research (score of 4.5/5). Online education offers the possibility of creating "international classrooms" or "global classrooms" with students from different parts of the world with different cultures, characteristics and training experiences [40]. In this context, knowing how to efficiently manage such diverse groups was considered a priority by our participating teachers. In addition, the importance of knowing how to provide detailed and personalized feedback was considered a fundamental characteristic that online tutors should develop, with a rating of $4.4 / 5$. Feedback is fundamental since it helps students understand their strengths and weaknesses and gives teachers an opportunity to promote reflection in learning and create a continuum throughout 
the course and thus generate even deeper and more significant knowledge [41]. For the feedback process to have satisfactory results, there are three influencing variables: the pedagogical skills of the tutor, the activity level of the students and the shared effort between the two [42]. The online tutors who were surveyed rated the ability of the tutor to assess the adequacy of the content and teaching materials very positively. This characteristic is directly related to the efficient combination of pedagogical knowledge with the use of technology. To this end, it is also important for tutors to understand what type of content and materials are appropriate for online teaching and learning, taking into account the needs of their students. For example, many online teachers post videos with instructions and presentations on content related to their subject. Such content is not accessible to students living in China. Therefore, teachers must be able to assess the best way for all students to have the same learning opportunities. Another example is the access to and use of materials for students with special educational needs. Subjects may have predetermined content and materials, but the tutor must ensure that these contents and materials are suitable for everyone. Finally, reference is made to the importance of relating the contents of the subject with real life. This is confirmed by recent literature, since, according to the 2016 Horizon Report, "deeper learning" is the most important trend in higher education [43]. Specifically, this term was defined as a pedagogy that combines critical thinking, problem solving, collaboration and self-directed learning. In this context, it is clear that students must be able to connect the curriculum, knowledge and skills they acquire with the real world. Our participants believe that this competence provides a framework for transformative learning that has the potential to support the development and success of each student.

\subsection{Training needs}

The 250 participating teachers used a scale from 1 (lowest score) to 5 (highest score) to evaluate 20 competencies/characteristics that are a training priority for online tutors according to the corresponding bibliography. The competencies/characteristics that obtained the highest score (mean) are presented in Figure 6.

Almost all of the participants rated the need for training in communication tools as highly important (4.9/5). It is true that in any educational process, communication is essential. However, in the context of e-learning, communication becomes more important [44]. This is because the communication tools used will determine how students exchange knowledge, resolve doubts, share experiences and create a sense of community [45]. There are several types of communication tools that can be integrated into e-learning programs to support learning and training activities. Some tools may be included in the virtual platforms that are used for the university, such as chats, wikis, forums or blogs. However, we can go further, using external tools such as social networks or synchronous communication software (Zoom, Collaborate, etc.). This need is consistent with the fundamental capacity assessed in the previous chapter of "experience in synchronous and asynchronous communication". Along the same lines, we can see that tutors want training on how to promote interaction in the virtual class- 
room and how to manage the virtual community that is created in the context of an online subject

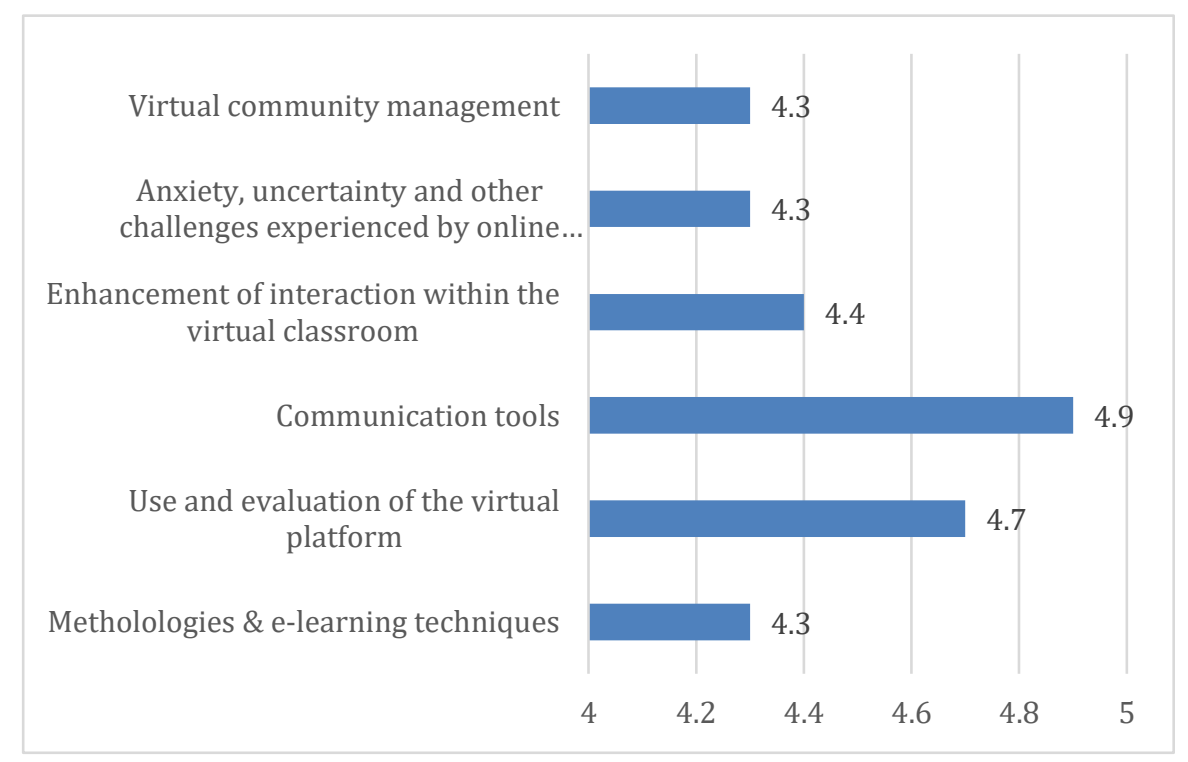

Fig. 6. Mean assessment of the online tutor's training needs

The primary role of the online tutor is to make the appropriate mechanisms available to students to facilitate the learning process [46]. These mechanisms involve designing activities that promote interaction among students, motivate the discussion of the contents and compel the search for information [47]. Additionally, the teacher must be able to design teaching activities that consider the learning needs of students and the possibility of adapting to the different learning styles and rhythms of the group [48]. In educational contexts that integrate technology into the teaching and learning processes, the teacher is expected to have a deep knowledge of the subject he or she teaches as well as of the basic didactic and pedagogical principles for efficient teaching. Teachers are asked to constantly update the application of these technologies in terms of both their use and the optimal design of learning activities that take advantage of these tools.

The need to receive training on the evaluation and editing of the virtual learning platform has also been identified. The platform not only allows us to do our work in a manner aligned with the times but also makes it easier for us to use and distribute our time better, and it allows us to provide feedback on students' work and evaluate projects, exams or tests without the need to physically review each assignment [49]. In this context, it is essential that the tutor know how to edit and manage the virtual platform, adapting the tools and materials according to the characteristics and needs of their students. This training need is in line with the competence that was identified 
as "fundamental" in the previous section on evaluating the efficiency of content and teaching materials.

Finally, an interesting need identified by the participating tutors is related to factors that cause anxiety and uncertainty and generally have a negative impact the performance of online students. According to Bolliger and Halupa [50], the factors linked to the satisfaction of online students are experience in using technology and flexibility. Other authors mention tutor behavior, reliable technology and interactivity [51]. The perceptions of the students regarding the value of the task and self-efficacy, social capacity, instructional design problems, the quality of the virtual learning platform and the use of multimedia programs and tools are also important elements [52].

\section{Conclusion}

The online training process is different from face-to-face training. In the e-learning model, the students are more autonomous and study independently, without geographical limitations and at their own pace. According to this modern pedagogical approach, the instructor becomes the guide of the student in the learning process. The teacher's work is closer to what a "mentor" does, allowing information to become knowledge, as well as providing students with necessary tools and resources. In this context, tutors should be equipped with a set of appropriate skills and competencies, in addition to thematic knowledge. Therefore, selection of the online teaching team becomes a critical success factor that also contributes to the acceptance of virtual learning as a "quality modality". This selection process is especially important when the model of education in universities is modified from a traditional approach to one in which teaching is facilitated through the Internet. However, considering the challenges of acquiring duly qualified tutors, the teaching team should include, at minimum, people willing to acquire the necessary skills described in this work. This implies the establishment of adequate support mechanisms for tutors to receive training prior to their first virtual teaching session. Consequently, "support for online learning" could be defined as an appropriate method to facilitate learning through the use of a set of skills, such as computer skills and experience with pedagogical uses of elearning resources. This will enable us distinguish the three fundamental success factors related to the support of online teaching: online tutoring skills, online learning skills and specifically designed online learning facilities.

Once this research is completed and the conclusions obtained are expressed, we believe, as other authors have proposed, that qualitative studies that consider the quality of online teachers from different points of view should be conducted. Although there is a great deal of literature on the profile of the online tutor, there are very few studies that relate it to the concept of quality in higher education. It would also be worth investigating this topic in different geographical areas in which e-learning has different levels of acceptance and evolution/development. In the same vein, we consider that professional training opportunities that are available to online tutors at universities that are not exclusively dedicated to online teaching could be compared to those available at universities that specialize in e-learning. 
We insist that research should also be qualitative because the qualitative perspective allows us to focus on subjective issues, such as feelings, perceptions, effects, etc., namely, everything that we can access through an approach to the object of study (online tutors).

\section{$5 \quad$ References}

[1] Kontogeorgos, A. (2012). Quality assurance in higher education. Good practices. Retrieved from http://modip.teilam.gr/files/1_Basikes_ennoies.pdf [in Greek].

[2] Shelton, K. (2011). A review of paradigms for evaluating the quality of online education programs. Online Journal of Distance Learning Administration, 14(1). Retrieved from https://www.learntechlib.org/p/52626

[3] Vlachopoulos, D. (2016). Assuring quality in e-learning course design: the roadmap. The International Review of Research in Open and Distributed Learning. 17(6), 183-205. https://doi.org/10.19173/irrodl.v17i6.2784

[4] Xu, H., Jilenga, M. T., \& Deng, Y. (2019). Institutional Quality, Resource Endowment, and Economic Growth: Evidence from Cross-Country Data. Emerging Markets Finance \& Trade, 55(8), 1754-1775. https://doi.org/10.1080/1540496x.2018.1496418

[5] Tremblay, K., \& Kis, V. (2008). Assuring and improving quality. In A P. Santiego, Trmblay, K., Basri, E. \& Arnal E. Tertiary education for the knowledge society - Volume 1: Special features: Governance, funding, quality (pp. 259-322). Paris: Organisation de coopération et de développement economiques.

[6] Albor, G. R., Lorduy, V. G., \& Dau, M. A. (2014). Quality of higher education for distance and virtual learning. Investigación \& Desarrollo, 22(1): 79-120.

[7] Grant, A. (2010). Tearing down the walls: creating global classrooms through online teacher preparation programs. Distance Learning, 7(2), 37-41.

[8] McPherson, M.A. \& Nunes, J.M. (2004). Developing Innovation in Online Learning: An Action Research Framework. London: RoutledgeFalmer.

[9] Phelps, A. \& Vlachopoulos, D. (2020). Successful transition to synchronous learning environments in distance education: a research on entry-level synchronous facilitator competencies. Education and Information Technologies, 25: 1511-1527. https://doi.org/10.1007/ $\underline{\text { s10639-019-09989-x }}$

[10] Llorente, M.C. (2006). El tutor en E-learning: aspectos a tener en cuenta. Revista electrónica de Tecnología Educativa, 20. Retrieved from http://edutec.rediris.es/Revelec2/ revelec20/llorente.htm. https://doi.org/10.21556/edutec.2006.20.517

[11] Fernández-Jiménez, M.A., Tójar-Hurtado, J.C., \& Mena-Rodríguez, E. (2013). Evaluación de buenas prácticas de tutorización e-learning. Funciones del teletutor y su papel en la formación. Píxel-Bit. Revista de Medios y Educación, 43: 85-98. https://doi.org/10.12795/pixelbit.2013.i43.08

[12] McGuiness, N. \& Vlachopoulos, D. (2019). Student Experiences of Using Online Material to Support Success in A-Level Economics. International Journal of Emerging Technologies in Learning 14(3),80-109. https://doi.org/10.3991/ijet.v14i03.9406

[13] Sangrà, A., Vlachopoulos, D. \& Cabrera, N. (2012). The conceptual framework of elearning: a view from inside. International Journal of Learning. 18(4): 93-104. https://doi. org/10.18848/1447-9494/cgp/v18i04/47573

[14] Adnan, M., Kalelioglu, F., \& Gulbahar, Y. (2017). Assessment of a Multinational Online Faculty Development Program on Online Teaching: Reflections of Candidate E-Tutors. 
Turkish Online Journal of Distance Education, 18(1): 22-38. https://doi.org/10.17718/ tojde. 285708

[15] Ferencz, T. S. (2017). Shared Perceptions of Online Adjunct Faculty in the United States Who Have a High Sense of Community. Journal of Educators Online, 14(2). Retrieved from https://pdfs.semanticscholar.org/c06e/dbc4f46f6790130b82978f86f401c69084ae.pdf. https://doi.org/10.9743/jeo.2017.14.2.6

[16] Walters, S., Grover, K. S., Turner, R. C., \& Alexander, J. C. (2017). Faculty Perceptions Related to Teaching Online: A Starting Point for Designing Faculty Development Initiatives. Turkish Online Journal of Distance Education, 18(4): 4-19. https://doi.org/10.17718/ tojde. 340365

[17] Thorpe, S. J. (2016). Online Facilitator Competencies for Group Facilitators. Group Facilitation: A Research \& Applications Journal.13, 79-90.

[18] Gros, B., Lara, P., García, I., López, X., Maniega, J., Martínez, T. (2012). El model educatiu de la UOC. Evolució i perspectives. Barcelona: Universitat Oberta de Catalunya. https://doi.org/10.7238/uoc

[19] UOC. (2017). El model educatiu segons els graduats. Retrieved from http://estudis. uoc.edu/ca/model-educatiu-graduats

[20] Williams, S., Sunderman, J., \& Kim, J. (2012). E-mentoring in an Online Course: Benefits and Challenges to E-mentors. International Journal of Evidence Based Coaching \& Mentoring, 10(1): 109-123.

[21] Portugal, L. M. (2015). Work Ethic, Characteristics, Attributes, and Traits of Successful Online Faculty. Online Journal of Distance Learning Administration, 18(1). Retrieved from https://www.westga.edu/ distance/ojdla/spring181/portugal181.html

[22] Allen, I. E., \& Seaman, J. (2014). Grade change: Tracking online education in the United States. Needham, MA: Sloan-Consortium.

[23] Helton, C., \& Helton, C. (2005). Mentoring distance learning faculty from a distance. Society for Information Technology and Teacher Education International Conference. Chesapeake.

[24] Yazici, H., \& Altun, F. (2013). Type-A behavior, gender, and job satisfaction: A research on instructors. Educational Sciences: Theory \& Practice, 13(3): 1455-1459.

[25] Gappa, J.M., Austin, A.E., \& Trice, A.C. (2007). Rethinking faculty work: Higher education's strategic imperative. San Francisco, CA: Jossey-Bass. https://doi.org/10.1007/ s10734-009-9222-0

[26] Mandernach, J., Register, L., \& O'Donnell, C. (2015). Characteristics of Adjunct Faculty Teaching Online: Institutional Implications. Online Journal of Distance Learning Administration, 18(1). Retrieved from https://eric.ed.gov/?id=EJ1055073

[27] Rosen, L. (2010). Rewired: Understanding the iGeneration and the Way They Learn. New York, NY: Palgrave MacMillan

[28] Ornellas, A. \& Romero, M. (2011). La planificació col-laborativa de la docència en línia. Retrieved from http://cv.uoc.edu/annotation/20c490ecb89e4afb6f04f87b4c3b89c8/ 485129/PID 00178140/modul 6.html\#w26aac17b7

[29] Mueller, B., Mandernach, J.B. \& Sanderson, K. (2013). Adjunct versus Full-Time Faculty:

[30] Comparison of Student Outcomes in the Online Classroom. MERLOT Journal of Online Learning and Teaching, 9(3): 341-352.

[31] Marsh, H. W. (2007). Do university teachers become more effective with experience? A multilevel growth model of students' evaluations of teaching over 13 years. Journal of Educational Psychology, 99(4): 775-790. https://doi.org/10.1037/0022-0663.99.4.775

[32] Bedford, L. \& Miller, H. (2013). All adjuncts are not created equal: An exploratory study of teaching and professional needs of online adjuncts. Online Journal of Distance Learning 
Administration, 15(1). Retrieved from https://www.westga.edu/ distance/ojdla/spring161/ bedford miller.html

[33] Cohen, L. \& Manion, L. (2002). Métodos de investigación educativa. Madrid: La Muralla.

[34] Denzin, N. \& Lincoln, Y. (2005). The SAGE Handbook of Qualitative Research. Thousand Oaks, California: Sage Publications.

[35] Silverman, D. (2013). Doing Qualitative Research. London, UK: Sage.

[36] Robson, C. (2011). Real World Research. West Sussex, UK: Wiley.

[37] Kaplan, D. (2004). The SAGE Handbook of Quantitative Methodology for the Social Sciences. Thousand Oaks, California: Sage Publications.

[38] Bonett, D. G., \& Wright, T. A. (2015). Cronbach's alpha reliability: Interval estimation, hypothesis testing, and sample size planning. Journal of Organizational Behavior, 36(1): 315. https://doi.org/10.1002/job.1960

[39] Bens, I. (2005). Facilitating with ease: Core skills for facilitators, team leaders and members, managers, consultants, and trainers. San Francisco, CA: JosseyBass. https://doi. org/10.5465/amle.2007.25223472

[40] Burke, P., Frischknecht, B., Schuck, S., Aubusson, P., \& Kearney, M. (2018). Exploring teacher pedagogy, stages of concern and accessibility as determinants of technology adoption. Technology, Pedagogy And Education, 27(2): 149-163. https://doi.org/10.1080/ 1475939x.2017.1387602

[41] Hua, Z., Handford, M., \& Young, T. (2017). Framing interculturality: a corpus-based analysis of online promotional discourse of higher education intercultural communication courses. Journal of Multilingual and Multicultural Development, 38(3): 283-300. https://doi.org/10.1080/01434632.2015.1134555

[42] Alvarado García, M. A. (2014). Retroalimentación en educación en línea: una estrategia para la construcción del conocimiento. RIED. Revista Iberoamericana de Educación a Distancia, volumen 17(2): 59-73. https://doi.org/10.5944/ried.17.2.12678

[43] Jackson, G. \& Graesser, A. (2006). Aplicaciones del dialogo humano de tutoria al Auto Tutor: un sistema inteligente de turoría. Revista Signos, 39(60), 31-48. https://doi. org/10.20868/upm.thesis.66047

[44] NMC. (2016). Horizon report- Higher Education Edition. Retrieved from http://cdn. nmc.org/media/2016-nmc-horizon-report-he-EN.pdf

[45] Peechapol, C., Na-Songkhla, J., Sujiva, S. \& Luangsodsai, A. (2018). An Exploration of Factors Influencing Self-Efficacy in Online Learning: A Systematic Review. International Journal of Emerging Technologies in Learning, 13(9): 64-86. https://doi.org/ 10.3991/ijet.v13i09.8351

[46] Cunningham, P. (2017). Bridging the distance: Using interactive communication tools to make online education more social. Library Trends, 65(4): 589-613. https://doi. org/10.1353/lib.2017.0020

[47] Chaves Torres, A. (2017). La educación a distancia como respuesta a las necesidades educativas del siglo XXI. Revista Academia y Virtualidad, 10(1): 23-41. https://doi.org/ $\underline{10.18359 / \text { ravi.2241 }}$

[48] Rodríguez, N. (2014). Fundamentos del proceso educativo a distancia: enseñanza, aprendizaje y evaluación. Revista Iberoamericana de Educación a Distancia RIED, 17(2): 75-93. https://doi.org/10.5944/ried.17.2.12679

[49] Fraga, L.M. \& Harmon, J. (2015). The Flipped Classroom Model of Learning in Higher Education: An Investigation of Preservice Teachers' Perspectives and Achievement. Journal of Digital Learning in Teacher Education, 31(1): 18-27. https://doi.org/10.1080/ $\underline{21532974.2014 .967420}$ 
[50] Frida, A.B. \& Hernández, R. G. (1999). Estrategias Docentes para un aprendizaje Significativo. Mexico: McGraw-Hill.

[51] Bolliger, D. U., \& Halupa, C. (2012). Student perceptions of satisfaction and anxiety in an online doctoral program. Distance Education, 33(1): 81-98. https://doi.org/10.1080/ $\underline{01587919.2012 .667961}$

[52] Dennen, V. P., Darabi, A. A., \& Smith, L. J. (2007). Instructor-learner interaction in online courses: The relative perceived importance of particular instructor actions on performance and satisfaction. Distance Education, 28: 65-79. https://doi.org/10.1080/01587910 $\underline{701305319}$

[53] Bahati, B., Fors, U., Hansen, P., Nouri, J. \& Mukama, E. (2019). Measuring Learner Satisfaction with Formative e-Assessment Strategies. International Journal of Emerging Technologies in Learning, 14(7): 61-79. https://doi.org/10.3991/ijet.v14i07.9120

\section{Authors}

Dimitrios Vlachopoulos is program manager of the track "EdTech for Social Change" at Amsterdam University of Applied Sciences. Since 2005, he has been working as faculty member in different universities in the Netherlands, the UK, Greece, the USA, Spain and Cyprus. He is a committed lifelong learner with a PhD in distance education and instructional technology and 6 MA degrees in education and social sciences. He is a Senior Fellow of the Higher Education Academy (SFHEA) and Fellow of the Royal Society of Arts (FRSA). Dimitrios has more than 90 publications in peer-reviewed journals, books and international conferences and has participated in more than 15 EU projects related to education and ICT.

Agoritsa Makri received her PhD in "Education Sciences" at the European University Cyprus (School of Humanities, Social and Education Sciences). Her scientific interests include e-learning models, innovative technology, interaction and collaboration in e-learning settings, educational games, and online research methods.

Article submitted 2020-11-30. Resubmitted 2021-01-14. Final acceptance 2021-01-14. Final version published as submitted by the authors. 